\title{
Evaluating Paenibacillus odorifer for its potential to reduce shelf life in reworked high-temperature, short-time fluid milk products
}

Casey E. Rush, Jared Johnson, Samantha Burroughs, Brandon Riesgaard, Alejandro Torres, Lisbeth Meunier-Goddik, and Joy Waite-Cusic*

\section{Graphical Abstract}

Evaluating Paenibacillus odorifer for its potential to reduce shelf-life in reworked HTST fluid milk products
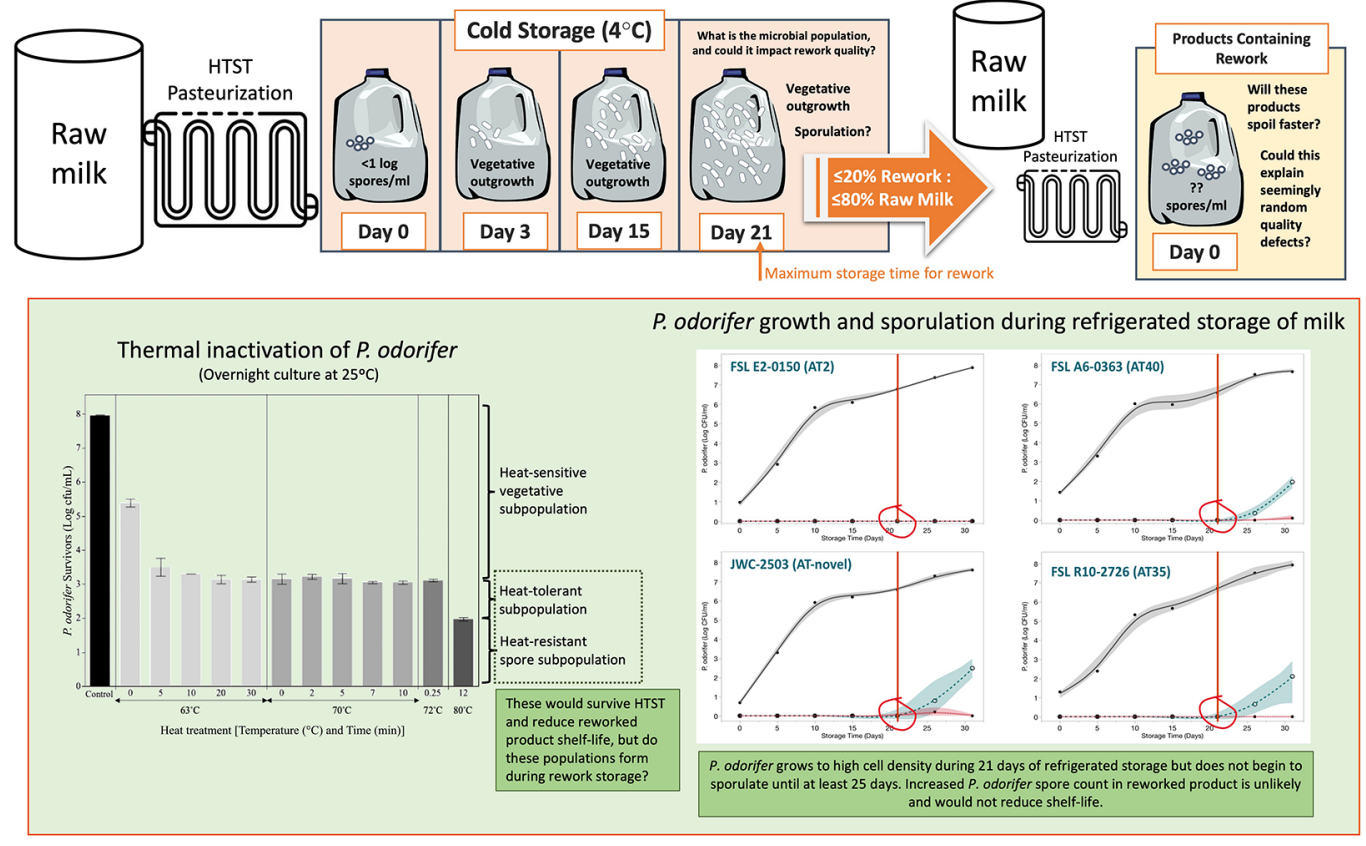

\section{Summary}

Rework practices used by the dairy industry have the potential to negatively influence product quality; however, this has not been previously investigated. The goal of this study was to use Paenibacillus odorifer, a problematic spore-forming spoilage bacterium, as the target organism to quantify growth rates, thermal resistance, and sporulation during the storage phase of product destined for rework. This study demonstrated the growth potential of $P$. odorifer during refrigerated storage of chocolate and unflavored milk and the inability for $P$. odorifer to sporulate in these products within their maximum shelf life and potential use in rework applications. Due to the heat sensitivity of $P$. odorifer vegetative cells, this study indicates that current rework practices are unlikely to lead to increased milk spoilage associated with this bacterium.

\section{Highlights}

- Paenibacillus odorifer does not sporulate within the shelf life of HTST (high-temperature, short-time) milk.

- The microbial quality of reworked milk products is unlikely to be affected by $P$. odorifer.

- We found evidence of a $P$. odorifer subpopulation surviving $72^{\circ} \mathrm{C} / 15 \mathrm{~s}$, but not $80^{\circ} \mathrm{C} / 12 \mathrm{~min}$.

Food Science and Technology, Oregon State University, Corvallis 97331. *Corresponding author: joy.waite-cusic@oregonstate.edu. @ 2022, The Authors. Published by Elsevier Inc. and Fass Inc. on behalf of the American Dairy Science Association ${ }^{\circledast}$. This is an open access article under the CC BY license (http:// creativecommons.org/licenses/by/4.0/). Received September 02, 2021. Accepted November 21, 2021. 


\title{
Evaluating Paenibacillus odorifer for its potential to reduce shelf life in reworked high-temperature, short-time fluid milk products
}

\author{
Casey E. Rush, Jared Johnson, Samantha Burroughs, Brandon Riesgaard, Alejandro Torres, \\ Lisbeth Meunier-Goddik, and Joy Waite-Cusic*
}

\begin{abstract}
Rework is a common practice used in the dairy industry as a strategy to help minimize waste from processing steps or errors that might otherwise render the product unsaleable. Dairy processors may rework their high-temperature, short-time (HTST) fluid milk products up to code date $(21 \mathrm{~d})$ at a typical dilution rate of $\leq 20 \%$ rework into $\geq 80 \%$ fresh raw milk. Bacterial spores present in raw milk that can survive pasteurization and grow at refrigeration temperatures are often responsible for milk spoilage. However, the potential impact of growth and thermal resistance of organisms in reworked product has not been investigated. Our objective was to characterize growth, sporulation, and thermal resistance of Paenibacillus odorifer under conditions representative of extreme storage conditions (time and temperature) of reduced fat $(2 \%)$ and chocolate milk to evaluate whether product containing rework would have a reduced shelf life. Commercial UHT-pasteurized $2 \%$ milk and chocolate milk were independently inoculated with 4 strains of $P$. odorifer at 1 to 2 log $\mathrm{cfu} / \mathrm{mL}$ and stored at $4^{\circ} \mathrm{C}$ and $7^{\circ} \mathrm{C}$ for $30 \mathrm{~d}$. Changes in $P$. odorifer cell densities were determined by standard serial dilution with spread plating on tryptic soy agar with yeast extract and incubation at $25^{\circ} \mathrm{C}$ for $48 \mathrm{~h}$. Spore counts were determined following thermal treatment at $80^{\circ} \mathrm{C}$ for $12 \mathrm{~min}$. Thermal resistance of a cocktail of $P$. odorifer in milk was determined after treatments at $63^{\circ} \mathrm{C}$ for 30 min and $72^{\circ} \mathrm{C}$ for $15 \mathrm{~s}$. Strains of $P$. odorifer grew rapidly at $7^{\circ} \mathrm{C}$ and reached a maximum cell density of $\sim 8 \log$ cfu $/ \mathrm{g}$ in both $2 \%$ and chocolate milk within $12 \mathrm{~d}$. All strains grew more slowly at $4^{\circ} \mathrm{C}$ and had not reached maximum cell density by $21 \mathrm{~d}$. With extreme temperature abuse $\left(25^{\circ} \mathrm{C}, 24 \mathrm{~h}\right)$, P. odorifer will sporulate in milk; however, thermally resistant subpopulations, including spores, did not develop in milk at $4^{\circ} \mathrm{C}$ until after stationary phase was achieved $(>24 \mathrm{~d})$. Vegetative cells of $P$. odorifer were verified to be sensitive to pasteurization $(>7$ $\log$ reduction); therefore, $P$. odorifer would not be expected to contribute to reduced shelf life of fluid milk products containing rework, even with extended storage before rework.
\end{abstract}

$Q^{-1}$ uality defects and premature spoilage of pasteurized fluid milk is commonly caused by the growth of psychrotrophic microorganisms. There are 2 primary sources of spoilage organisms in fluid dairy products: heat-resistant psychrotrophic sporeformers from raw milk that survive the pasteurization process and psychrotrophic post-pasteurization contaminants (Alvarez, 2009; Trmčić et al., 2015; Martin et al., 2018). Post-pasteurization contaminants are commonly gram-negative bacteria present in the dairy processing environment that must be mitigated through sanitation programs (Gopal et al., 2015; Reichler et al., 2018). Bacillus and Paenibacillus spores are commonly found in raw milk and are collected during milking from the farm environment (Meer et al., 1991; Coorevits et al., 2008; Huck et al., 2008). These spores survive HTST pasteurization treatments $\left(72^{\circ} \mathrm{C}, 15 \mathrm{~s}\right)$ and germinate and grow under refrigeration conditions (Washam et al., 1977; Collins, 1981; Huck et al., 2007). Sporogenesis is an adaptive characteristic triggered when a vegetative cell is placed in unfavorable environmental conditions (e.g., lack of nutrients, unfavorable storage temperature). When conditions are favorable, the spore can germinate into a vegetative cell, and replication then proceeds (Gauvry et al., 2017). Paenibacillus spp. are the dominant genus found at elevated levels ( $\geq 6 \log \mathrm{cfu} / \mathrm{mL}$ ) in pasteurized milk at the end of shelf life (Huck et al., 2008; Ranieri and Boor,
2009; Ivy et al., 2012). Quality defects have been reported to occur at cell densities $>6.0 \mathrm{log} \mathrm{cfu} / \mathrm{mL}$ for milk products contaminated with Paenibacillus spp., including off-flavors and textural changes resulting from proteolysis and lipolysis (Fromm and Boor, 2004; Alvarez, 2009; Ivy et al., 2012).

Management of microbial quality of milk is further complicated for dairy processors using reworking practices to minimize waste. According to the Dairy Practices Council, rework is defined as, "Clean, unadulterated food that has been removed from processing for reasons other than insanitary conditions or that has been successfully reconditioned by reprocessing and that is suitable for use as food" (Dairy Practices Council, 2005). The source of product to be reworked has commonly failed a quality standard, often due to underfilled containers, cosmetic packaging flaws, unsold product (products approaching sell-by date), elevated microbial counts, leakers, or diluted product reclaimed from the fillers between product changeovers and following clean-in-place (CIP) procedures. Dairy processors commingle these products with raw milk, resulting in a fresh product with a new code date. Common dilution rates used by the industry are $20 \%$ rework for unflavored milk and $10 \%$ rework for chocolate-flavored milk products (Rush et al., 2021). The timeframe for reworking HTST-pasteurized products typically falls between 14 and $22 \mathrm{~d}$, with flavored products having a shorter 
shelf life (Ranieri and Boor, 2009). Products contaminated with psychrotrophic bacteria at the time of packaging can reach cell densities of $>6.0 \log \mathrm{cfu} / \mathrm{mL}$ within this timeframe (Douglas et al., 2000; Buehler et al., 2018; Beno et al., 2020). If these organisms survived pasteurization, they could have a negative effect on the shelf life of the newly processed product. Although there have been no prior investigations into microbiological quality implications of reworking milk products, processors report increased microbial cell densities and frequent flavor defects in reworked products compared with products that do not contain rework (Rush et al., 2021).

The majority (59\%) of Paenibacillus spp. isolated from dairy products and dairy environments are Paenibacillus odorifer (Beno et al., 2020). Spores of $P$. odorifer germinate following pasteurization and replicate in pasteurized milk throughout its refrigerated shelf life (Beno et al., 2020). Paenibacillus odorifer has been demonstrated to grow in skim milk, whole milk, or skim milk broth (SMB) at $6^{\circ} \mathrm{C}$ and to reach final cell densities of $>4 \log \mathrm{cfu} / \mathrm{mL}$ within $14 \mathrm{~d}$ (Beno et al., 2020) and $>6 \log \mathrm{cfu} / \mathrm{mL}$ within $21 \mathrm{~d}$ (Ivy et al., 2012; Moreno Switt et al., 2014). The growth rate of $P$. odorifer in SMB has been modeled at $4^{\circ} \mathrm{C}(0.4 \log \mathrm{cfu} / \mathrm{mL}$ per day); however, minimum growth temperature for $P$. odorifer is typically reported as $5^{\circ} \mathrm{C}$ (Berge et al., 2002).

There are multiple stages of fluid milk production where potential $P$. odorifer contamination, growth, and sporulation could pose an elevated risk in reworked product. First is the contamination level of $P$. odorifer spores in raw milk. Psychrotrophic spore density in fluid milk averages 1 spore $/ 6 \mathrm{~mL}$ of raw milk $(-0.79 \mathrm{log}$ spores/mL; Buehler et al., 2018). Pasteurization will shock these spores to germinate in packaged product and grow during potential onsite storage of milk destined for rework. Growth behavior of $P$. odorifer in SMB at $6^{\circ} \mathrm{C}$ has been reported as an estimate of growth potential during distribution, retail, and consumer storage. However, dairy processing facilities typically have more consistent temperature control, and milk products held for rework are stored at $\leq 4^{\circ} \mathrm{C}$. Growth of $P$. odorifer has been predicted, but not confirmed, at $4^{\circ} \mathrm{C}$ (Buehler et al., 2018). This information is necessary to determine the microbial burden of milk that will be diluted into fresh product and repasteurized. Although it is known that $P$. odorifer spores survive pasteurization, there is a lack of information on the heat resistance of vegetative cells and no evidence to indicate whether $P$. odorifer would sporulate in milk under these storage conditions. Martin et al. (2018) reported that a spoilage event can occur in a product container in which only 1 spore is present. If high levels of $P$. odorifer spores develop in milk products during the storage period before rework, then increased spoilage would be likely for milk products containing rework (Vissers et al., 2007; Buehler et al., 2018). Understanding the time and temperature conditions that lead to $P$. odorifer sporulation could guide dairy processors to limit the storage time of milk that might be reworked to minimize premature spoilage.

Our overall objective was to determine the potential effect of $P$. odorifer on milk products containing rework. This study was designed to characterize growth and behavior of $P$. odorifer in reduced fat $(2 \%)$ and chocolate milk stored under conditions used by the dairy industry before reworking into fresh product. Growth rates, maximum cell density, and thermal resistance are critical parameters to determine the potential impact of $P$. odorifer on fluid milk products containing rework.
Strains of $P$. odorifer representing diverse $r p o B$ allele types (AT) were used in this study: FSL A6-0363 (AT40), FSL R10-2726 (AT35), FSL E2-0150 (AT2), and JWC-2503 (AT1922). The first 2 strains were originally isolated from pasteurized milk and the latter 2 from pasteurized chocolate milk. Isolates were revived from frozen storage $\left(-80^{\circ} \mathrm{C}\right)$ by transferring to tryptic soy broth with $0.3 \%$ yeast extract (TSBYE, Neogen) with incubation at $25^{\circ} \mathrm{C}$ for $24 \mathrm{~h}$. Cultures were streaked for isolation on tryptic soy agar plates supplemented with $0.3 \%$ yeast extract (TSAYE, Neogen) and incubated at $25^{\circ} \mathrm{C}$ for $48 \mathrm{~h}$. A single isolated colony of each strain was independently transferred into TSBYE and incubated at $25^{\circ} \mathrm{C}$ for $24 \mathrm{~h}$. The resulting culture was serially diluted in $0.1 \%$ peptone water (Neogen) to a final cell density of $6 \log \mathrm{cfu} / \mathrm{mL}$, which served as the inoculum.

Ultra-high temperature pasteurized reduced fat (2\%) fluid milk (Lactalis American Group) and lowfat (1\%) chocolate milk (Nestlé USA Inc.) products were purchased at retail. Milk $(1,500 \mathrm{~mL})$ was aseptically transferred to Whirl-Pak bags (Nasco) and stomached for $30 \mathrm{~s}$. Each bag was inoculated with a single $P$. odorifer strain to a final cell density of 1 to $2 \log \mathrm{cfu} / \mathrm{mL}$. Inoculated milk samples were aliquoted $(200 \mathrm{~mL})$ into sterile $237-\mathrm{mL}$ plastic jars (Uline) in triplicate and incubated at $4^{\circ} \mathrm{C}$ and $7^{\circ} \mathrm{C}$ for $31 \mathrm{~d}$. The cell density of $P$. odorifer was determined by standard serial dilution $(0.1 \%$ peptone water) and spread plating on TSAYE with incubation at $25^{\circ} \mathrm{C}$ for $48 \mathrm{~h}$. Growth rates were determined using JMP Pro v16 software (SAS Institute Inc.) by applying a line of fit to the exponential growth phase for each strain.

For thermal inactivation studies, each $P$. odorifer strain was transferred to $25 \mathrm{~mL}$ of reduced-fat milk and incubated at $25^{\circ} \mathrm{C}$ for $24 \mathrm{~h}$. Cultured milk samples were combined and shaken for $30 \mathrm{~s}$ to create a $P$. odorifer cocktail and stored at $4{ }^{\circ} \mathrm{C}$ for $24 \mathrm{~h}$ before use. Aliquots $(900 \mu \mathrm{L})$ of reduced fat milk were transferred into microcentrifuge tubes and inoculated with $100 \mu \mathrm{L}$ of $P$. odorifer cocktail to a cell density of $8 \log \mathrm{cfu} / \mathrm{mL}$. A dry heating block (Benchmark Dry Bath) was used to treat milk samples at $63^{\circ} \mathrm{C}$ for 0 to $30 \mathrm{~min}$, $70^{\circ} \mathrm{C}$ for 0 to $10 \mathrm{~min}, 72^{\circ} \mathrm{C}$ for $15 \mathrm{~s}$ (HTST), and $80^{\circ} \mathrm{C}$ for $12 \mathrm{~min}$ (spore count). Thermal treatments were performed in triplicate. A thermocouple (EL-USB-TC-LCD, ThermoWorks) was held in an uninoculated milk sample to monitor temperature to establish come-up time. Heat-treated samples were immediately transferred to ice and survivors were enumerated using plating methods described above.

Growth of individual $P$. odorifer strains over the course of the 21 -d shelf life of fluid milk products at $4^{\circ} \mathrm{C}$ and $7^{\circ} \mathrm{C}$ is shown in Figure 1 . This information is relevant because the dairy industry may rework packaged product that has been stored under refrigerated conditions for 3 to $21 \mathrm{~d}$ before incorporating as rework into fresh product (Rush et al., 2021). All 4 strains were able to grow in both reduced fat and chocolate milk at both temperatures. Maximum growth rates over the first 7 to $10 \mathrm{~d}$ were similar between unflavored and flavored milk products for all strains at both temperatures $\left(4^{\circ} \mathrm{C}=0.39-0.53 \log \mathrm{cfu} / \mathrm{mL}\right.$ per day; $7^{\circ} \mathrm{C}=0.83-0.98$ $\log \mathrm{cfu} / \mathrm{mL}$ per day). Similar growth rates for $P$. odorifer in whole milk $\left(7^{\circ} \mathrm{C}=1.01 \mathrm{cfu} / \mathrm{mL}\right.$ per day $)$ and $\mathrm{SMB}\left(6^{\circ} \mathrm{C}=0.6 \mathrm{cfu} / \mathrm{mL}\right.$ per day) have been reported (Buehler et al., 2018; Sun et al., 2021); however, this is the first report of $P$. odorifer growing at temperatures below $5^{\circ} \mathrm{C}$ (Berge et al., 2002; Priest, 2015), as predicted by Buehler et al. (2018). 
A) FSL R10-2726 (pasteurized milk source)

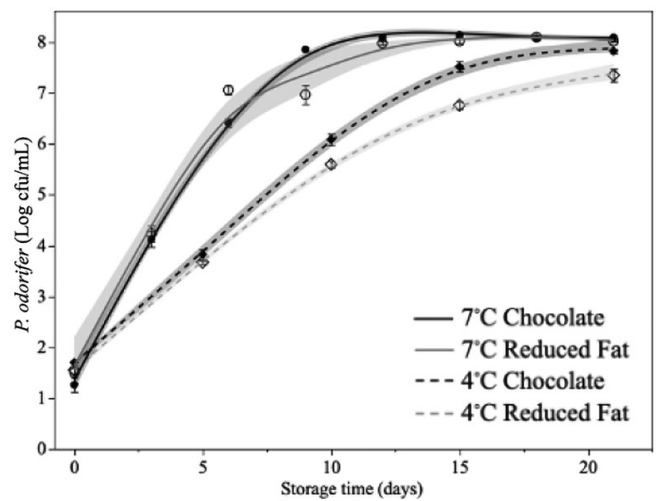

C) FSL E2-0150 (chocolate milk source)

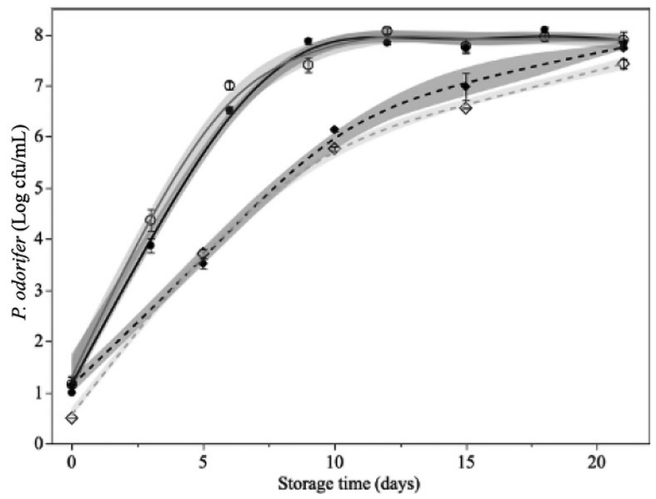

B) FSL A6-0363 (pasteurized milk source)

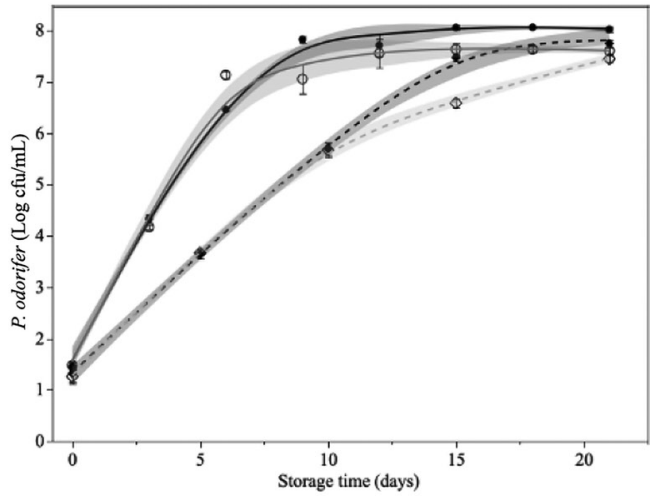

D) JWC-2503 (chocolate milk source)

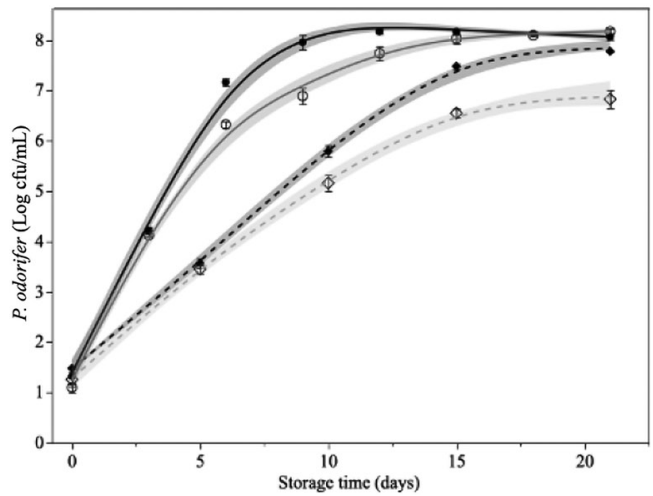

Figure 1. Growth behavior of Paenibacillus odorifer strains (A) FSL R10-2726, (B) FSL A6-0363, (C) FSL E2-0150, and (D) JWC-2503 in chocolate and reduced fat milk stored at $4^{\circ} \mathrm{C}$ and $7^{\circ} \mathrm{C}$ for $21 \mathrm{~d}$. Data points indicate mean log cfu $/ \mathrm{mL}(n=3) \pm$ standard error.

All strains demonstrated slower growth and a lower cell density after $21 \mathrm{~d}$ of storage at $4^{\circ} \mathrm{C}$ in unflavored milk $(6.83-7.45 \mathrm{log} \mathrm{cfu} /$ $\mathrm{mL})$ than in chocolate milk $(7.74-7.83 \log \mathrm{cfu} / \mathrm{mL})$. This difference in growth was most obvious for $P$. odorifer JWC-2503 (Figure 1D). This strain was originally isolated from a spoiled chocolate milk product and demonstrated improved growth in chocolate milk compared with reduced-fat milk. Paenibacillus odorifer FSL E20150 was also originally isolated from chocolate milk but grew equally well in both products (Figure 1C). The observed increased growth rate and final cell density in chocolate milk may be attributed to the addition of sucrose, as increased growth of $P$. odorifer has been noted in media supplemented with sucrose (Priest, 2015). There is little discussion of chocolate milk spoilage in the published literature, with no specific information on the growth of $P$. odorifer. Faster spoilage rates of commercial chocolate milk products, including the lack of a lag phase compared with unflavored milk growth curves have been reported (Orleans, 2011). Increased growth rates of some strains of $P$. odorifer in chocolate milk may contribute to the reduced shelf life of chocolate milk reported by processors.

A primary goal of these experiments was to determine the maximum cell density of $P$. odorifer in milk after $21 \mathrm{~d}$ of storage in order to quantify the potential microbial contribution when mixed with raw milk for reprocessing. Previous research on fluid milk spoilage has focused on microbial growth at 6 to $7^{\circ} \mathrm{C}$ to mimic temperatures during distribution, at retail, and throughout storage in home refrigerators, whereas the storage temperature for milk held for rework is tightly controlled at $4^{\circ} \mathrm{C}$. After $21 \mathrm{~d}$ of storage, $P$. odorifer ranged from 6.8 to $7.5 \mathrm{log} \mathrm{cfu} / \mathrm{mL}$ at $4^{\circ} \mathrm{C}$ and 7.6 to $8.2 \mathrm{log}$ $\mathrm{cfu} / \mathrm{mL}$ at $7^{\circ} \mathrm{C}$ (Figure 1). The mean cell density of JWC-2503 at $4^{\circ} \mathrm{C}(6.8-0.2 \mathrm{cfu} / \mathrm{mL})$ was lower than that of all other strains held at this temperature $(7.4-7.5 \mathrm{cfu} / \mathrm{mL})$.

Thermal inactivation experiments were performed to estimate the efficacy of pasteurization to reduce high cell density populations $(>7 \log \mathrm{cfu} / \mathrm{mL})$ of $P$. odorifer present in milk destined for rework (Figure 2). Initial $P$. odorifer cell density in milk subjected to thermal treatments was $7.9 \log \mathrm{cfu} / \mathrm{mL}$. As milk was heated to $63^{\circ} \mathrm{C}$ (come-up time), the count of the cocktail was reduced to $5.4 \log \mathrm{cfu} / \mathrm{mL}$ (2.5 log reduction) indicating high sensitivity of $P$. odorifer to thermal inactivation. After a 5-min holding time at $63^{\circ} \mathrm{C}, 3.5 \log \mathrm{cfu} / \mathrm{mL}$ of $P$. odorifer remained viable. No further reduction of $P$. odorifer was achieved with additional treatment at $63^{\circ} \mathrm{C}$ for up to $30 \mathrm{~min}$. Time and temperature combinations of $63^{\circ} \mathrm{C}$ for 5 to $30 \mathrm{~min}, 70^{\circ} \mathrm{C}$ for 0 to $10 \mathrm{~min}$, and $72^{\circ} \mathrm{C}$ for 15 $\mathrm{s}$ did not differ in their lethality toward the $P$. odorifer cocktail, with survivors ranging between 3.0 and $3.1 \log \mathrm{cfu} / \mathrm{mL}$. These results indicated presence of a thermally resistant subpopulation of $P$. odorifer. The inoculation preparation procedure $\left(25^{\circ} \mathrm{C}, 24\right.$ 
h) for the thermal inactivation study likely supported initiation of $P$. odorifer sporulation. Additional inoculated milk samples were heat-treated at $80^{\circ} \mathrm{C}$ for $12 \mathrm{~min}$, demonstrating a spore population of $2.0 \log \mathrm{cfu} / \mathrm{mL}$ in the milk. Thermal resistance of Paenibacillus spores has been recorded in the literature; however, the emphasis has been on spores that display excessive thermal resistance. For example, Paenibacillus spores survived heat treatments up to $120^{\circ} \mathrm{C}$ for $30 \mathrm{~s}$ (te Giffel et al., 2002). Furthermore, Paenibacillus species have been isolated from UHT-pasteurized milk $\left(280^{\circ} \mathrm{C}\right.$, 2 s) (Scheldeman et al., 2004; Deeth, 2017). Overall, our results indicate that vegetative cells of $P$. odorifer are extremely sensitive to heat and would be easily inactivated by HTST pasteurization, even at high cell densities, and thus would not pose an increased spoilage risk for reworked milk. However, due to high thermal resistance of $P$. odorifer spores and perhaps another thermoduric cell type, it is critical to determine whether these thermally resistant subpopulations develop in milk held at refrigeration for extended periods.

A second growth study of $P$. odorifer strains in fluid milk at $4^{\circ} \mathrm{C}$ was performed to monitor development of thermally resistant subpopulations with extended storage (Figure 3). All P. odorifer isolates displayed a similar rapid growth rate $(0.40-0.52 \mathrm{log} \mathrm{cfu} /$ $\mathrm{mL}$ per day) in fluid milk during the first $10 \mathrm{~d}$ of storage. However, between 10 and $15 \mathrm{~d}$, no growth was observed for any of the isolates, and cell density stalled at 5.3 to $6.2 \log$ cfu/mL. Paenibacillus odorifer transitioned into a second slower growth phase (0.09-0.14 $\log \mathrm{cfu} / \mathrm{ml} / \mathrm{d}$ ) from $15 \mathrm{~d}$ to 25 or $30 \mathrm{~d}$. This growth pattern was not obvious in the previous growth studies at $4{ }^{\circ} \mathrm{C}$ reported in Figure 1. Further review of the previous data identified a similar pattern for $P$. odorifer growth at $7^{\circ} \mathrm{C}$ in milk (Figure 1); however, the stall occurred earlier (5-9 d) and at higher cell density (6.3-7.4 log cfu/

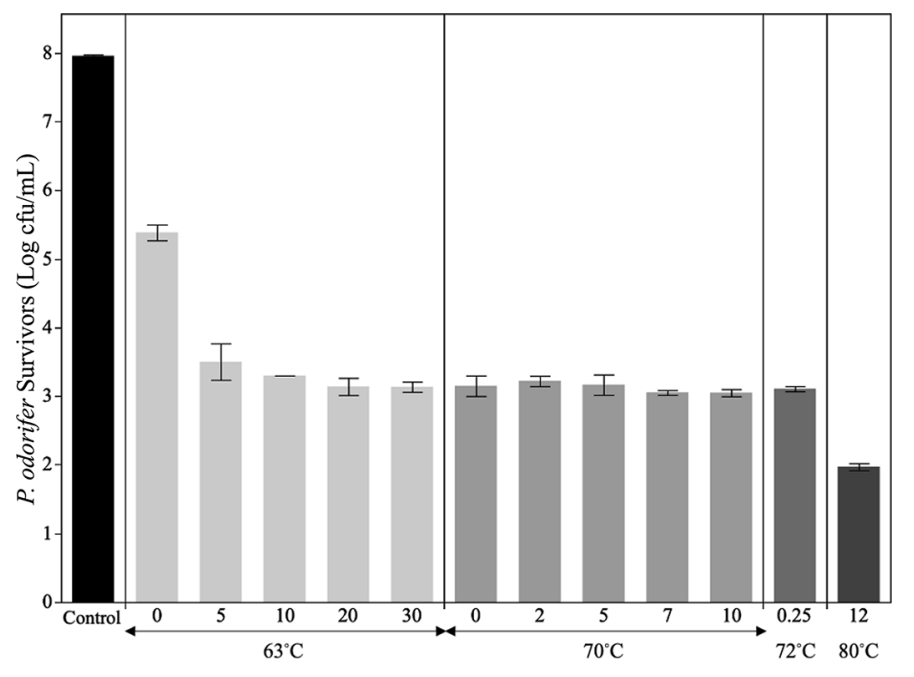

Heat treatment [Temperature $\left({ }^{\circ} \mathrm{C}\right)$ and Time $\left.(\min )\right]$

Figure 2. Thermal inactivation of Paenibacillus odorifer cocktail grown in pasteurized reduced fat milk at $25^{\circ} \mathrm{C}$ for $24 \mathrm{~h}$. Data are displayed as mean \pm standard error $(n=3)$. Bars labeled as a treatment time of 0 min represent inactivation due to the come-up time at each temperature. Treatment at $80^{\circ} \mathrm{C}$ for $12 \mathrm{~min}$ is the standard thermal treatment for enumeration of bacterial spores.
$\mathrm{mL})$. This diauxic behavior may be linked to depletion of a primary carbon or nitrogen source followed by transition and utilization of a secondary nutrient source (Chu and Barnes, 2016).

For the first $21 \mathrm{~d}$ of storage in inoculated milk at $4^{\circ} \mathrm{C}$, the $P$. odorifer population was highly sensitive to thermal treatment $(>6.5$ $\log$ reduction at $72^{\circ} \mathrm{C}, 15 \mathrm{~s}$ ) and was presumed to be completely composed of vegetative cells (Figure 3 ). We continued to incubate samples beyond the 21-d shelf life to determine whether thermally resistant subpopulations could develop under refrigeration conditions. Thermally resistant subpopulations $\left(72^{\circ} \mathrm{C}, 15 \mathrm{~s}\right)$ were first detected at $26 \mathrm{~d}$; however, detection was intermittent across replicates, suggesting a recent change. Paenibacillus odorifer FSL R10-2726 had a resistant subpopulation of $1.95 \mathrm{log} \mathrm{cfu} / \mathrm{mL}$ (vegetative count: $8.00 \log \mathrm{cfu} / \mathrm{mL}$ ) in one sample replicate, whereas JWC-2503 and FSL A6-0363 had low levels of resistant cells (0.3 and $2.4 \log \mathrm{cfu} / \mathrm{mL}$ ) in 2 replicates. With continued storage (31 d), thermally resistant subpopulations of $P$. odorifer were detected in milk samples inoculated with FSL R10-2726, JWC-2503, and FSL A6-0363, ranging between 0.30 and $3.12 \mathrm{log} \mathrm{cfu} / \mathrm{mL}$. Paenibacillus odorifer FSL E2-1050 did not develop a thermally resistant subpopulation. Data suggest that strains developed resistant subpopulations as they approached their maximum cell density (stationary phase), whereas FSL E2-1050 was still actively replicating (Figure 3 ). Only one inoculated milk sample (one replicate of FSL A6-0363) produced a single surviving cell (0.3 log cfu/ $\mathrm{mL}$ ) after treatment at $80^{\circ} \mathrm{C}$ for $12 \mathrm{~min}$ (spore count). It is possible that continued incubation at $4^{\circ} \mathrm{C}$ would have resulted in further development of thermally resistant subpopulations of all strains. Collectively, these results suggest that $P$. odorifer may transition to a cell type with intermediate thermal resistance that is distinct from a true bacterial spore. Research on the sporulation process of Paenibacillus polymyxa has identified several subpopulations differing in size and membrane integrity (Comas-Riu and VivesRego, 2002). These results also suggest that utilizing the standard thermal treatment for spore counts (Frank and Yousef, 2004) may underestimate populations of $P$. odorifer that could survive pasteurization and affect milk quality. The recommended process for spore enumeration $\left(80^{\circ} \mathrm{C}, 12 \mathrm{~min}\right)$ was based on the thermal resistance of a variety of mesophilic and thermophilic sporeformers (Warth, 1978). No psychrotrophic sporeformers were included in that study, and the authors report a correlation of maximum growth temperature and spore death temperature, suggesting that psychrotrophic sporeformers may be underestimated by this method. Sun et al. (2021) also considered this methodological concern and opted to enumerate $P$. odorifer spores following a thermal treatment of $63^{\circ} \mathrm{C}$ for $30 \mathrm{~min}$. Additional research on thermal treatments for quantification of psychrotrophic spores or other heat-resistant bacterial subpopulations would facilitate improved understanding of the source and behavior of Paenibacillus on farm and during raw milk handling.

The overall objective of our research was to evaluate the potential impact of $P$. odorifer as a spoilage organism in milk containing rework. This study demonstrated that $P$. odorifer is capable of rapid growth and achieves high cell density in both reduced fat and chocolate milk stored at $4^{\circ} \mathrm{C}$ and $7^{\circ} \mathrm{C}$. We demonstrated that vegetative cells of $P$. odorifer are sensitive to pasteurization treatments; however, this species can develop thermal resistant subpopulations. Although these thermal resistant subpopulations can 
A) FSL R10-2726

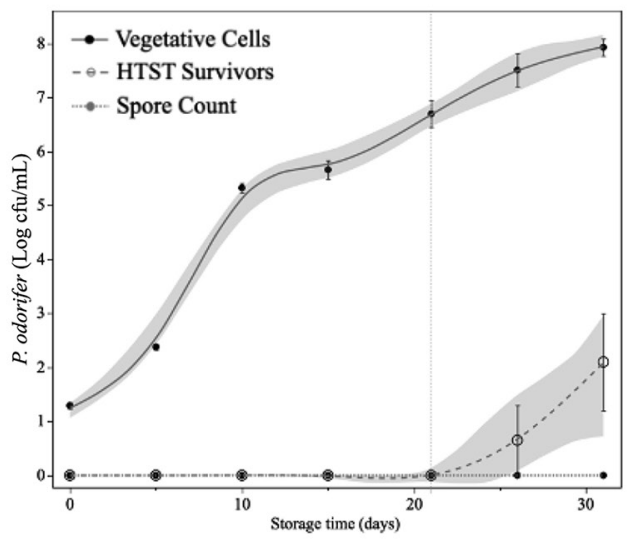

C) FSL E2-0150

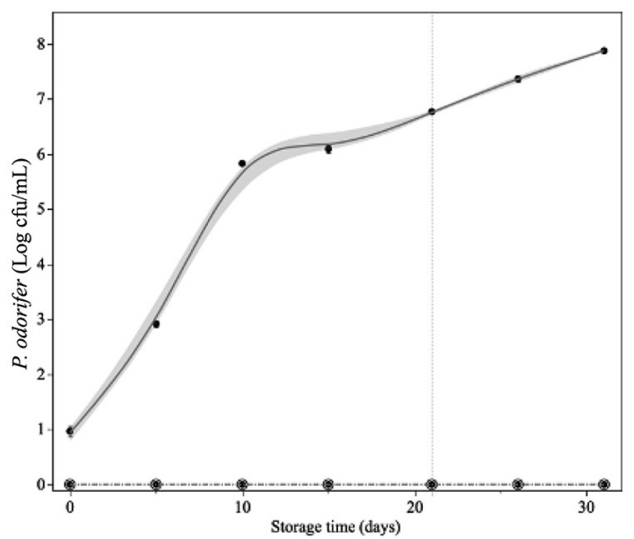

B) FSL A6-0363

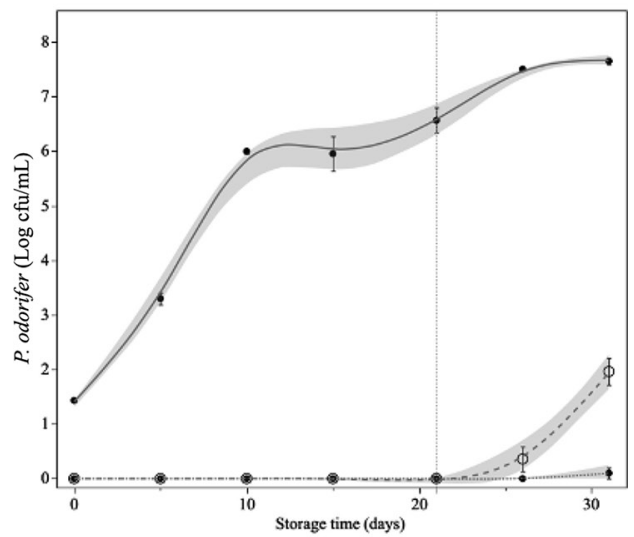

D) JWC-2503

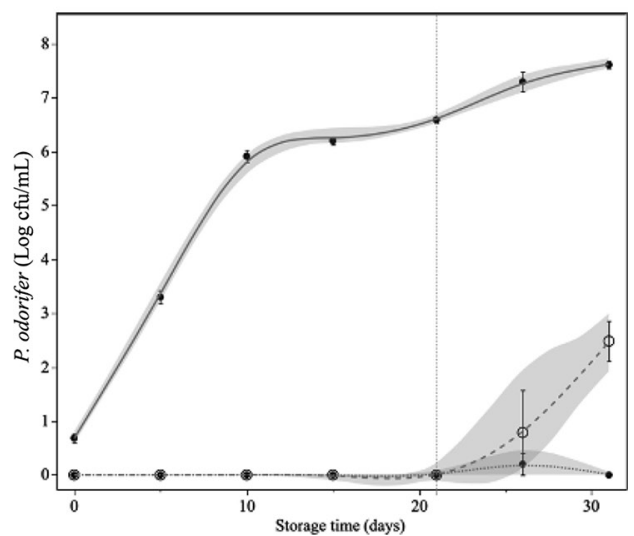

Figure 3. Growth and sporulation of Paenibacillus odorifer strains (A) FSL R10-2726, (B) FSL A6-0363, (C) FSL E2-0150, and (D) JWC-2503 in fluid milk (2\%) stored at $4^{\circ} \mathrm{C}$ for $31 \mathrm{~d}$. HTST survivors and spore counts were subpopulations that survived thermal treatments of $72^{\circ} \mathrm{C}$ for $15 \mathrm{~s}$ and $80^{\circ} \mathrm{C}$ for $12 \mathrm{~min}$, respectively. Data points indicate mean $\log \mathrm{cfu} / \mathrm{mL}(\mathrm{n}=3) \pm$ standard error. The dashed line at $21 \mathrm{~d}$ indicates the typical end of shelf life and the last potential day to use as rework. Samples with no recovered colonies are reported as equivalent to the detection limit of $0 \log \mathrm{cfu} / \mathrm{mL}(1 \mathrm{cfu} / \mathrm{mL})$.

survive pasteurization, we demonstrate that they do not develop in fluid milk samples stored at $4^{\circ} \mathrm{C}$ for up to $21 \mathrm{~d}$ (maximum storage time before rework) and therefore are unlikely reduce the shelf life of milk products containing rework in alignment with the Pasteurized Milk Ordinance (US Food and Drug Administration, 2017). Paenibacillus odorifer is unlikely to contribute to the reduced shelf life of fluid and flavored milk products containing rework.

\section{References}

Alvarez, V. 2009. Fluid milk and cream products. Pages 73-133 in The Sensory Evaluation of Dairy Products. 2nd ed. S. Clark, M. Costello, M. Drake, and F. Bodyfelt, ed. Springer-Verlag.

Beno, S. M., R. A. Cheng, R. H. Orsi, D. R. Duncan, X. Guo, J. Kovac, L. M. Carroll, N. H. Martin, and M. Wiedmann. 2020. Paenibacillus odorifer, the predominant Paenibacillus species isolated from milk in the United States, demonstrates genetic and phenotypic conservation of psychrotolerance but clade-associated differences in nitrogen metabolic pathways. mSphere 5:e00739-19. https://doi.org/10.1128/mSphere.00739-19.

Berge, O., M. H. Guinebretière, W. Achouak, P. Normand, and T. Heulin. 2002. Paenibacillus graminis sp. nov. and Paenibacillus odorifer sp. nov., isolated from plant roots, soil and food. Int. J. Syst. Evol. Microbiol. 52:607-616. https://doi.org/10.1099/00207713-52-2-607.
Buehler, A. J., N. H. Martin, K. J. Boor, and M. Wiedmann. 2018. Psychrotolerant spore-former growth characterization for the development of a dairy spoilage predictive model. J. Dairy Sci. 101:6964-6981. https://doi.org/10 $.3168 /$ jds.2018-14501.

Chu, D., and D. J. Barnes. 2016. The lag-phase during diauxic growth is a trade-off between fast adaptation and high growth rate. Sci. Rep. 6:25191. https://doi.org/10.1038/srep25191.

Collins, E. B. 1981. Heat resistant psychrotrophic microorganisms. J. Dairy Sci. 64:157-160. https://doi.org/10.3168/jds.S0022-0302(81)82543-X.

Comas-Riu, J., and J. Vives-Rego. 2002. Cytometric monitoring of growth, sporogenesis and spore cell sorting in Paenibacillus polymyxa (formerly Bacillus polymyxa). J. Appl. Microbiol. 92:475-481. https://doi.org/10 .1046/j.1365-2672.2002.01549.x.

Coorevits, A., V. De Jonghe, J. Vandroemme, R. Reekmans, J. Heyrman, W. Messens, P. De Vos, and M. Heyndrickx. 2008. Comparative analysis of the diversity of aerobic spore-forming bacteria in raw milk from organic and conventional dairy farms. Syst. Appl. Microbiol. 31:126-140. https:// doi.org/10.1016/j.syapm.2008.03.002.

Dairy Practices Council. 2005. Guidelines for controlling the quality and use of dairy product rework. Dairy Practices Council. https://www.dairypc.org/ products/guidelines.

Deeth, H. 2017. Optimum thermal processing for extended shelf-life (ESL) milk. Foods 6:102. https://doi.org/10.3390/foods6110102. 
Douglas, S. A., M. J. Gray, A. D. Crandall, and K. J. Boor. 2000. Characterization of chocolate milk spoilage patterns. J. Food Prot. 63:516-521. https:// doi.org/10.4315/0362-028X-63.4.516.

Frank, J., and A. Yousef. 2004. Tests for groups of microorganisms. Pages 227-247 in Standard Methods of the Examination of Dairy Products. 17th ed. H. Wehr and J. Frank, ed. American Public Health Association.

Fromm, H. I., and K. J. Boor. 2004. Characterization of pasteurized fluid milk shelf-life attributes. J. Food Sci. 69:M207-M214. https://doi.org/10.1111/j .1365-2621.2004.tb09889.x.

Gauvry, E., A. G. Mathot, I. Leguérinel, O. Couvert, F. Postollec, V. Broussolle, and L. Coroller. 2017. Knowledge of the physiology of spore-forming bacteria can explain the origin of spores in the food environment. Res. Microbiol. 168:369-378. https://doi.org/10.1016/j.resmic.2016.10.006.

Gopal, N., C. Hill, P. R. Ross, T. P. Beresford, M. A. Fenelon, and P. D. Cotter 2015. The prevalence and control of Bacillus and related spore-forming bacteria in the dairy industry. Front. Microbiol. 6:1418. https://doi.org/10 $.3389 /$ fmicb.2015.01418.

Huck, J. R., B. H. Hammond, S. C. Murphy, N. H. Woodcock, and K. J. Boor. 2007. Tracking spore-forming bacterial contaminants in fluid milkprocessing systems. J. Dairy Sci. 90:4872-4883. https://doi.org/10.3168/ jds.2007-0196.

Huck, J. R., M. Sonnen, and K. J. Boor. 2008. Tracking heat-resistant, coldthriving fluid milk spoilage bacteria from farm to packaged product. J. Dairy Sci. 91:1218-1228. https://doi.org/10.3168/jds.2007-0697.

Ivy, R. A., M. L. Ranieri, N. H. Martin, H. C. den Bakker, B. M. Xavier, M. Wiedmann, and K. J. Boor. 2012. Identification and characterization of psychrotolerant sporeformers associated with fluid milk production and processing. Appl. Environ. Microbiol. 78:1853-1864. https://doi.org/10 .1128/AEM.06536-11.

Martin, N. H., K. J. Boor, and M. Wiedmann. 2018. Symposium review: Effect of post-pasteurization contamination on fluid milk quality. J. Dairy Sci. 101:861-870. https://doi.org/10.3168/jds.2017-13339.

Meer, R. R., J. Baker, F. W. Bodyfelt, and M. W. Griffiths. 1991. Psychrotrophic Bacillus spp. in fluid milk products: A review. J. Food Prot. 54:969-979. https://doi.org/10.4315/0362-028X-54.12.969.

Moreno Switt, A. I., A. D. Andrus, M. L. Ranieri, R. H. Orsi, R. Ivy, H. C. den Bakker, N. H. Martin, M. Wiedmann, and K. J. Boor. 2014. Genomic comparison of sporeforming bacilli isolated from milk. BMC Genomics 15:26. https://doi.org/10.1186/1471-2164-15-26.

Orleans, K. A. 2011. Microbiological and chemical changes during shelf-life in regular and chocolate milk. MS Thesis. Department of Food Science and Technology, The Ohio State University, Columbus.

Priest, F. G. 2015. Paenibacillus. In Bergey's Manual of Systematic Bacteriology Online. John Wiley \& Sons Inc.

Ranieri, M. L., and K. J. Boor. 2009. Short communication: Bacterial ecology of high-temperature, short-time pasteurized milk processed in the United States. J. Dairy Sci. 92:4833-4840. https://doi.org/10.3168/jds.2009-2181.
Reichler, S. J., A. Trmčić, N. H. Martin, K. J. Boor, and M. Wiedmann. 2018. Pseudomonas fluorescens group bacterial strains are responsible for repeat and sporadic postpasteurization contamination and reduced fluid milk shelf life. J. Dairy Sci. 101:7780-7800. https://doi.org/10.3168/jds.2018-14438.

Rush, C. E., L. Meunier-Goddik, and J. Waite-Cusic. 2021. Rework practices used during milk processing: An industry survey. Food Prot. Trends. In press.

Scheldeman, P., K. Goossens, M. Rodriguez-Diaz, A. Pil, J. Goris, L. Herman, P. De Vos, N. A. Logan, and M. Heyndrickx. 2004. Paenibacillus lactis sp. nov., isolated from raw and heat-treated milk. Int. J. Syst. Evol. Microbiol. 54:885-891. https://doi.org/10.1099/ijs.0.02822-0.

Sun, L., K. Atkinson, M. Zhu, and D. D'Amico. 2021. Antimicrobial effects of a bioactive glycolipid on spore-forming spoilage bacteria in milk. J. Dairy Sci. 104:4002-4011. https://doi.org/10.3168/jds.2020-19769.

te Giffel, M. C., A. Wagendorp, A. Herrewegh, and F. Driehuis. 2002. Bacterial spores in silage and raw milk. Antonie van Leeuwenhoek 81:625-630. https://doi.org/10.1023/A:1020578110353.

Trmčić, A., N. H. Martin, K. J. Boor, and M. Wiedmann. 2015. A standard bacterial isolate set for research on contemporary dairy spoilage. J. Dairy Sci. 98:5806-5817. https://doi.org/10.3168/jds.2015-9490.

US Food and Drug Administration. 2017. Grade "A" Pasteurized Milk Ordinance (PMO) 1-426. Accessed 20 May 2021. https://www.fda.gov/media/ 114169/download.

Vissers, M. M. M., F. Driehuis, M. C. Te Giffel, P. De Jong, and J. M. G. Lankveld. 2007. Short communication: Quantification of the transmission of microorganisms to milk via dirt attached to the exterior of teats. J. Dairy Sci. 90:3579-3582. https://doi.org/10.3168/jds.2006-633.

Warth, A. D. 1978. Relationship between the heat resistance of spores and the optimum and maximum growth temperatures of Bacillus species. J. Bacteriol. 134:699-705. https://doi.org/10.1128/jb.134.3.699-705.1978.

Washam, C. J., H. C. Olson, and E. R. Vedamuthu. 1977. Heat-resistant psychrotrophic bacteria isolated from pasteurized milk. J. Food Prot. 40:101-108. https://doi.org/10.4315/0362-028X-40.5.329.

\section{Notes}

This study was funded by the BUILD Dairy (Logan, UT) with additional support from the Arbuthnot Dairy Center at Oregon State University (OSU; Corvallis).

The authors acknowledge Danton Batty (OSU) for his role in isolating $P$. odorifer JWC-2503 and Sarah Guffey (OSU) for her efforts on preliminary studies with this strain. A special thank you to Brandon Selover (OSU) for assistance with laboratory procedures. We also thank the Cornell University Food Safety Laboratory (Ithaca, NY) for assistance with rpoB allele-typing.

The authors have not stated any conflicts of interest. 